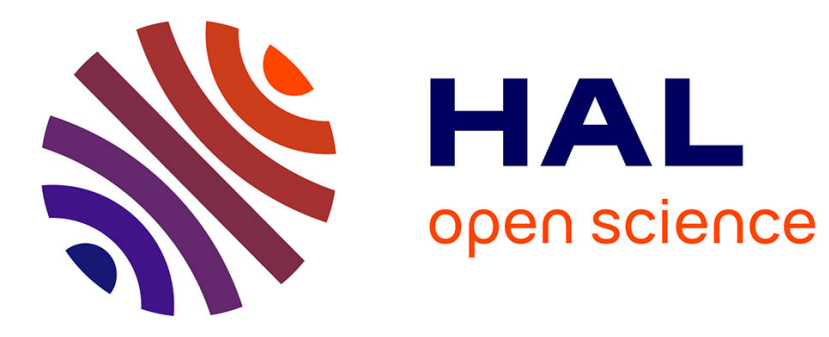

\title{
A radical subversion of the original shi'ism
}

Thierry Lamote

\section{To cite this version:}

Thierry Lamote. A radical subversion of the original shi'ism: The transformation of the Divine Guide into a "jurist-theologian". Recherches en psychanalyse, 2014, Psychanalyse et interdisciplinarité - II / Psychoanalysis and Interdisciplinarity - II, 2 (18), pp.198-207. 10.3917/rep.018.0188 . hal-01504862

\section{HAL Id: hal-01504862 \\ https://hal.science/hal-01504862}

Submitted on 14 Jun 2017

HAL is a multi-disciplinary open access archive for the deposit and dissemination of scientific research documents, whether they are published or not. The documents may come from teaching and research institutions in France or abroad, or from public or private research centers.
L'archive ouverte pluridisciplinaire HAL, est destinée au dépôt et à la diffusion de documents scientifiques de niveau recherche, publiés ou non, émanant des établissements d'enseignement et de recherche français ou étrangers, des laboratoires publics ou privés. 


\section{Recherches en Psychanalyse - Research in Psychoanalysis}

$18 \mid 2014$ - Psychoanalysis and Interdisciplinarity - II

Psychanalyse et interdisciplinarité - II

Varia

\section{A Radical Subversion of the Original Shi'ism}

The transformation of the Divine Guide into a "jurist-theologian"

Une subversion radicale du shîisme originel

La transformation du Guide divin en " juriste-théologien »

[Online] Dec. 26, 2014

Thierry Lamote

\section{Abstract:}

How did Shi'ism, which was traditionally a mystical form of quietism and initiation, culminate in the Iranian revolution that brought Khomeini to power? After investigating the Shi'ite origins of Khomeinism, we look at the place and the function of the "jurist theologian" using the Lacanian theory of the social bond. We discover that where there is a general tendency to see the dominance of an authoritarian master, there actually reigns a "rational" brand of theological and juridicial knowledge: a knowledge without a master, and which claims to rule over all.

\section{Résumé :}

Comment le shî'isme, traditionnellement mystique, initiatique et quiétiste, a-t-il pu aboutir à la révolution iranienne qui porta Khomeini au pouvoir ? Après avoir exploré les sources shî'ites du khomeinisme, nous envisagerons la place et la fonction du " juriste-théologien " à partir de la théorie lacanienne du lien social. Nous découvrirons alors que là où l'on tend à voir la domination d'un maître autoritaire ne règne en réalité que le savoir théologico-juridique " rationnel » : un savoir sans maître, qui prétend tout régenter.

Keywords: shi'ism, prophet, imam, quilting point, discourse of the master, discourse of the university Mots-clefs : shiisme, prophète, imâm, point de capiton, discours du maître, discours universitaire

\section{Plan :}

The Matrix of Shi'ism

"Discourse" and Social Bond

The Original Shi'ite Discourse

The Tipping Point, from the Imam to the Place of the Master

From The Occultation to Khomeinism

At the start of the 1970s, when Henri Corbin's monumental study En islam iranien ${ }^{1}$ was published, Corbin was still able to assert that Shi'ism - and in this respect it was, according to him, quite unlike Sunnism - possessed the doctrinal resources that were required in order to keep political power and spiritual authority apart: contrary to the caliph, ontologically alien to the Ta'wil (which opens a port of access to the original meaning of the Revelation), the imam effectively illustrates for the orientalist "a nonpolitical destination for Islam." ${ }^{2}$ 
How did this denomination of Islam, which traditionally was one of quietism, more concerned with mystical initiation and esoteric teaching than with temporal questions, come to culminate in a politico-religious movement that brought Ruhollah Khomeini to power? Should the Iranian revolution be envisaged as a symbolic solution that aimed to block the hegemony and ideology of the free market (which was just starting to spread during the last years of the Shah dictatorship) by restoring the discourse of the master and what would seem to be a consistent figure of authority? Based on the Lacanian theory of "discourses," ${ }^{3}$ which we shall be taking care to explicate in their different articulations, we shall attempt to ascertain, in the slight variations in sociality that have marked Shi'ite history, the various clues that heralded this major event long before it actually came to pass. We shall see, then, that where there is a tendency to view things in terms of the reign of an authoritarian master, there is in fact theological and judicial knowledge: an invasive knowledge that has been given over to its deployment and that controls the political field in its entirety.

\section{The Matrix of Shi'ism}

Upon the death of the Prophet Muhammad (year 11 of the Hijra) the question arose as to his succession. A majority of Muslims asserted that he had not designated any successor, and opted for the traditional manner of electing a chief: ${ }^{4}$ A council composed of his companions and influential members of some of the powerful Meccan tribes thus assigned to a sage from his tribe (the Quraysh) the task of electing the community's new Guide. It was thus that Abu Bakr became the first caliph, immediately dividing the nascent Muslim religion into two principal tendencies: one branch that would accept his caliphate, and another in which the partisans of Ali (the Prophet's cousin and son-inlaw) grouped together. ${ }^{5}$

The Alids ascribe the exclusive right to guide the community to the descendants of the Prophet.
They assert not only that Muhammad had on several occasions clearly designated Ali as his heir, but furthermore that to elect the Prophet's successor by the traditional manner was "contrary to the spirit of the Qur'an:" the imams, chosen by God, should be chosen on the basis of their proximity to the Prophet. Now, as well as being his first cousin (the most sacred familial bond that exists in Islam), Ali was married to Fatimah, Muhammad's daughter: this double link, at once a symbolic tie (the sacred bond of cousinhood) and a blood tie (through Fatimah, Ali's descendants were of the same bloodline as the Prophet) made him the sole legitimate Guide. The group of Alids thus formed the first "faction" 6 of the Islamic religion: rejecting the caliphate of $\mathrm{Abu} B \mathrm{Bakr}$, they made Ali their first "imam" - this being a major signifier in Shi'ite thought.

This disagreement at the origin over the legitimacy of the chief thus allows a Real to appear ${ }^{7}$, through which the fundamental antagonism in the Muslim community came to be manifested: the various denominations of Islam are thus a host of different ways of treating this Real symbolically. Once it had been named (iman, "the faith"), this Real was to generate the central religious notion of "ilm," the "initiatory Science:" the exceptional capacity to penetrate (and to transmit) the hidden dimension of divine revelation. For the majority denomination of Islam, which is what Sunnism was to become, this quality - a prerequisite for the guidance of Muslims - stemmed from the recognized manifest qualities of the Guide, who was thus able to be elected in the traditional manner. The minority group of the "proShi'ites" held that, on the contrary, the Guide, chosen by God, should be elected on the basis of certain nonmanifest qualities transmitted through his blood ties with the Prophet.

\section{"Discourse" and Social Bond}

The Imam therefore occupies an "axial" position in Shi'ism: he is the Guide through whom a point of access opens up to everything that is 
knowable about God - this is why his word touches upon the sacred. Does he, however, embody a figure of the master? It seems to us that he does not - at least as far as original Shi'ism is concerned. In reality, it appears that the imam cannot be dissociated from the prophet (and from his prophetic speech). So it is that they form a duo that is equivalent to the primordial pair of signifiers $\left(S_{1}-S_{2}\right)$, which Lacan takes as the minimal support of language and of the social bond: ${ }^{8}$ namely, the dyad "mastersignifier $\left(S_{1}\right) /$ second signifier $\left(S_{2}\right)^{\prime \prime}$ that lies at the base of the "discourse of the master." Formalized by Lacan in his Seminar The Other Side of Psychoanalysis, this discourse provides a way of writing the classical definition of the signifier: "The signifier $\left[\mathrm{S}_{1}\right]$ is that which represents a subject [\$] for another signifier $\left[\mathrm{S}_{2}\right]$ :"

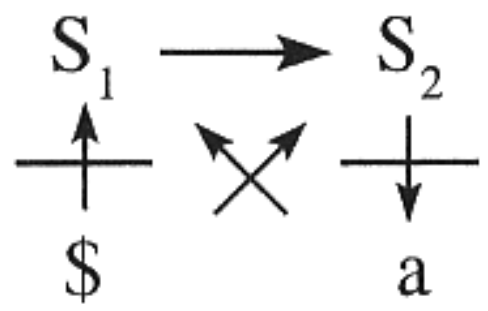

Figure 1: Matheme of the "discourse of the master"

We may add that each letter of this matheme is to be read against the matricial backdrop of the four places indicated below (" $\mathrm{S}_{1}$ " in the place of agent, " $\mathrm{S}_{2}$ " in the place of other, and so on):

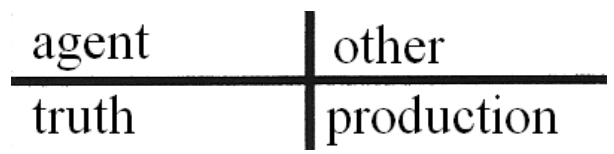

Figure 2: Table of the four places

Rather than appealing to the well-known image of the "stone covered in hieroglyphics" that Lacan formulated in The Four Fundamental Concepts of Psychoanalysis in order to illustrate his definition of the signifier, ${ }^{10}$ let us borrow the example proposed by Slavoj Žižek ${ }^{11}$ of the medical files that are displayed at the foot of the patients' beds in some hospitals, on which various details of the patient's state are listed. These technical annotations represent a host of master signifiers that represent the subject (\$); but for whom (or what) do they represent him? In being visible to anyone and everyone, they are addressed to those (nurses, doctors, etc.) who possess the knowledge to interpret them by appending further signifiers $\left(S_{2}\right)$ that ascribe a signification upon them. It would be erroneous to deduce from this that these signifiers represent the subject for another subject: these master signifiers do not simply represent the patient for the health care staff, but rather for the battery of medical signifiers by virtue of which the medical team will be able to interpret them. The $S_{1}$, the master signifier, is an "asemantic signifier:" in and of itself it does not refer to any signification whatsoever. In order to find its meaning retroactively, it needs to pass through the signifiers $\left(S_{2}\right)$ of the other. More precisely, the $S_{1}$ commands the knowledge $\left(S_{2}\right)$ of the other (and this is why the master signifier is in the place of the agent of the discourse, on the upper line on the left-hand side), and this $S_{2}$, in turn, confers a signification upon the $S_{1}$ : the very movement by which the $S_{1}$ gathers up this knowledge and gives order to it (which, without this $S_{1}$, would explode into an inconsistent multitude) allows it to find its meaning reflexively. The two go hand in hand: without the $S_{2}$, the $S_{1}$ has no meaning, it remains mute, referring only to its own place of empty inscription; without the $S_{1}$, the $S_{2}$ scatters into a proliferation of signifiers that are disordered and inconsistent. So it is that the $S_{1}$ exceeds its initial target (for example, indicating the patient's state to a doctor) in order to inscribe the subject, via the binary signifier $\left(S_{2}\right)$, in the vast symbolic network of the Other: in the end, it represents the subject with respect to the big Other - the long chain of medical knowledge, in our example. Furthermore, this excess is duplicated on the lower level of the matheme, because the articulation " $\mathrm{S}_{1}-\mathrm{S}_{2}$ ", in failing to represent the subject adequately (in our example, the subject is not only a sick patient, he is many other things besides - father, husband, teacher, etc.), produces a remainder (at the bottom on the right hand side): the object $a$, this piece of the real that puts up 
resistance when it is absorbed back into the signifier, and that recalls how the subject does not dissolve into the signifiers that represent him. But this failure is masked by the fact that all the elements that compose the subject are inscribed here at the place that might seem to be "naturally" attributed to them- the master $\left(S_{1}\right.$, the performative signifier) is in the place of the agent; the secondary signifier is on the side of the other; the remainder of the signifying operation (the object $a$ ) falls away in the place of the "product;" and so on and so forth. Now, not only does this coincidence participate in the performativity of the master (whose imposture it masks by the same stroke: in reality the master does not master anything, he remains divided and powerless - $\$$ ), but moreover it turns this discourse - into which any subject is inscribed by means of his every speech act into the matrix of all the other discourses that structure the social bond. Let us come back to the "prophet / imam" duo.

\section{The Original Shi'ite Discourse}

In spite of the efforts of the learned Shi'ites to try to "redress the balance" between prophet / imam relationships, or even to give a slight prevalence to the former (probably in a cautious staging of the Taqiyya, the obscure practice of "keeping secret," aiming to arrange a semblance of compromise with Sunnite dogmas of Orthodoxy in order to better protect certain esoteric points of the doctrine), it is still the case that the imam remains at the heart of popular devotion and learned thought: his ontological status of exception makes him "the Threshold that allows for passage to divine Science, the Science that is harbored in the messages carried by the legislating prophets," ${ }^{12}$ but whose interpretation alone is capable of revealing the esoteric truth - by which the mu'min (the true believer) is distinguished from the muslim (who is submitted to the literality of the text). How did the imam come to be inscribed in this preeminent place? Let us turn our attention here to the very first imam: Ali, the father of all imams. What happened when Muhammad proclaimed to his faithful followers during his speech at Ghadeer Khum not long before his death: "Let whoever considers me to be the object of his walayah henceforth take Ali as the object of his walayah?"13 These words had effects that stem from the intervention of the "quilting point."

The "quilting point" is used in mattress-making: it is the button tie that binds the upper layer of a mattress to its lower level, ensuring the minimal number of connections between the top and the bottom that are necessary to avoid constant slipping of one over the other. Lacan employed this term to offer an image of the effects of entering into the function of the father: ${ }^{14}$ this introduces the primordial signifiers that allow for an arrangement of signifier and signified in a certain relationship, by virtue of which not only does the signifying chain avoid becoming completely adrift in relation to the "amorphous mass" of the signified (which enables speakers to share a nimbus of common significations); furthermore, it also takes charge of a multitude of new significations. Walayah is one of the major signifiers of Shi'ite thought: it is the foremost Pillar of the Five Pillars of Islam the one "that determines the validity of all the Pillars and God's acceptance of them." ${ }^{15}$ In the field of Islamic religiosity, the full set of beliefs, practices and liturgy draws its holy meaning from its bond with the walayah, which is the most extraordinary manifestation of the Holy Light that inhabits God's chosen people. All the constitutive elements of Islamic holiness have value, therefore, only to the extent that they appear as epiphenomena of walayah. When this signifier emerges in the sentence uttered by Muhammad, its multiple significations had for a long time been inscribed in Islam's religious consciousness: in and of itself, it does not introduce anything new - which is precisely the specificity of the quilting point. However, its unexpected upsurge changes Ali's status in an instant: he who might have remained nothing more than one of the mere faithful (albeit the first among them) is suddenly elevated to the 
dignity of the holy Thing, becoming the object of the believers' veneration. The quilting point ("walayah") suddenly brings about this sleight of hand whereby all of Ali's qualities are transmuted into manifestations of his divine election: his words and his acts cease to be mere anecdotes and become the key moments of sacred history, laden with esoteric significations that lie in wait of deciphering. And this "veering of the entire field of signification," which in one fell swoop modifies Ali's ontological status, was likewise to bring with it powerful performative effects: the adepts who were exposed to these words from the Prophet were to see themselves immediately subjectively "pinpointed" in this speech - from that point forth, they would defend Ali as one of the most precious and most sacred elements of their devotion. In return, the performative power of his own words were to have the retroactive effect of sustaining the Prophet in his place as a master: the master whose founding word, a self- referential word, only harkens back to its own act of enunciation. We are now able to restore to each of the players the place that is allotted to him in the original Shi'ite discourse. Muhammad is the one through whom the master signifiers $\left(S_{1}\right)$ of Divine Revelation are expressed. But this text, such as it is revealed to the Prophet, remains enigmatic so long as one stays at the level of its manifest dimension, at the level of its Letter. In order to introduce the full set of significations that underlie the prophetic speech, the Letter needs to be infused with the Spirit that it lacks; that is to say, it is necessary to call upon interpretation (tawil) from the imam: only the deep knowledge of sacred things, which he draws from his walayah, from the Divine Light that dwells within him, authorizes the imam to bring out the esoteric meaning (the sole meaning that affords a point of access to divine things) of prophetic Revelation. In other words, in order to restore the original Shi'ite social bond in the framework of the discourse of the master: the man Muhammad here comes to the place of $\$$ (he remains a mere subject, divided and flawed), whereas the signifier "Prophet" and the prophetic words that represent him in his social function are inscribed in the place of the $S_{1}$, which orders the $S_{2}$ (the network of significations that are generated by the interpretation from the imam) to make its esoteric meaning emerge, which is a prerequisite for the initiation of the believers. The result of the operation is the object $a$, the fundamentally lacking (Real) object that marks the limits of the symbolic, and whose absence can only be revived (in the adept) through the imam's teaching by referring it back to the jouissance that lies at the next step of initiation. Thus, it is precisely this object, which is always already absent, produced by the tireless work of the imam, which will sustain and sharpen the desire of the "initiable believers" all along their initiatory path.

The Tipping Point, from the Imam to the Place of the Master

This distribution of the functions and places in the original Shi'ite discourse (into $S_{1}$, the revealed prophetic text that commands the interpretation; into $S_{2}$, the interpreting imam) was to change when the time came to give a doctrinal foundation to the new religion by establishing its dogmas and its canonical texts. The fifth and sixth imams, who are considered to be the "'founders' of imamite Shi'ism,"16 seem to have been the architects of this discursive turning point. The fifth imam, Muhammad al Baqir, renowned for his great piety, his vast learning and for the esoteric character of his teaching, was in effect, at first, to develop the quasi-definitive form of some of the chief doctrinal elements of imamite Shi'ism: "the couple of holy Alliance / holy Dissociation (walayah / Bara'a) [...]; the duty of keeping secret (taqiyya); to be a descendent of Fatimah, to harbor knowledge ( $\mathrm{i} / \mathrm{lm}$ ) and to possess an explicit text of investiture (nass) that is transmitted by the preceding imam, as the fundamental criteria of the imamat; the equality of rank between the imam and the Prophet in the transmission of sacred traditions; and lastly, the systematic 
development of specifically Shi'ite law." ${ }^{17}$ Then his son, Ja' far al Sadiq, the sixth imam, renowned in Muslim tradition as the wisest man of his time, who (like his father) had no political activity, took up the flame in order likewise to devote himself essentially to "consolidating the foundations of the doctrine that he represented and that he seems to have sought to systematize more than any other imam." ${ }^{18}$ The doctrinal activity of this learned man was such that he is generally considered to be the true developer of imamite Shi'a law, which is often named "Ja'farite law." Under the impulse of Muhammad al Baqir and Ja'far, via the introduction of new master signifiers $\left(S_{1}\right)$ that they were to produce in order to control the practices and reorganize the network of significations $\left(S_{2}\right)$ of that which was in the course of becoming the Shi'ite religion, the imam left his place as the interpreter of the prophetic text (his place as the other of the Prophet, in $\mathrm{S}_{2}$ ) in order to take up the reins of discourse (in the place of agent, $\mathrm{S}_{1}$ ). In coherence with this slide in their discursive position, both were to require of their pupils that they methodically set down in writing the teachings of the imams - which were thus to be inscribed among the master signifiers whose exegesis the adepts would have to perform - so as to constitute the first collections of the Shi'ite traditions. This repositioning of the imam in the place of the master was to be consolidated with the appearance, essentially under the imamat of Musa al Kadhim (the seventh imam, son of Ja'far), of "a new class of men of influence: the agents of the imam, who were responsible for the hierarchical organization of the faithful."19 Indeed, Shiism saw a remarkable expansion during this period, not only in the number of its adherents but (concomitantly) in the considerable sum of donations it received - in any case, these donations were sufficiently considerable to make the appearance of this new elite of representatives of the imam, who were distributed across the (now vast) territory of Shi'ism, a necessity. A stratification thus took shape in the Shi'ite sociality, proceeding from the installation of the imam in the position of the master and the consecutive emptying-out of the space of knowledge, a space that was called upon to be occupied by the various guardians of orthodoxy. In order to form a firm understanding of what was at stake in this re-articulation of the two poles $\left(S_{1}-S_{2}\right)$, we need to provide a rapid insight into one of the most fully accomplished developments of the discourse of the master: the societal model that for Hegel actualized the cutting edge of the Idea of the State, namely the "organically developed" state towards which parliamentary monarchy ought to tend.

Presented by Hegel in his Elements of the Philosophy of Right, ${ }^{20}$ this State is composed of three strata: civil society in which innumerable different individual interests come into ferocious conflict; a first institutional level - of corporations and other professional communities, administered by individuals who do not simply target their own private interest - whose objective is to subordinate these various particular interests to superior interests (those of corporations that are compatible with those of the State); and finally the public institutions that guarantee the free interplay of particular interests while seeing to it that there is a preservation of the "general interest, which, being the substance of all particular interests, includes the preservation of them also." ${ }^{21}$ To the complex stratification of civil society, we need therefore to add the stratification of the public institutions that are constituted by executive civil servants and their advisory agencies organized into colleges, converging "in the highest offices of all, which are in contact with the monarch." 22 How does this frightfully heterogeneous set of interests hold together to the extent of forming the organic Whole that was so admired by Hegel? Well, through the intervention of the monarch not because he would possess the best ability as far as his objective qualities are concerned (character, training and ideals) to support decision making, but precisely because his intervention eludes the objective framework of his "entitlements to office." ${ }^{23}$ Hegel tells us that what is at issue here is the appearance in the process of a pure "singularity," to be understood 
almost in its contemporary sense, that is to say, as that which breaks away from the rationality of the (deliberative) process. The complex functioning of the state machinery as a whole, whose missions are grounded in reason and whose tasks are carried through to completion thanks to the objective capacities of the individuals who go to make up this machine, is therefore organized and gathered together in a coherent Whole via the detour of an "irrational leap," ${ }^{24}$ as Žižek puts it quite rightly: the offcenter and self-referential intervention of the monarch, whose decision is founded solely on the pure act of enunciating a subjective "I will," ${ }^{25}$ which he signs in his name. Thus, the monarch truly is this master signifier $\left(S_{1}\right)$ whose intervention subjectifies the chain and orders, so that it does not scatter, the (objective) knowledge of the other (the various strata of bureaucracy, in $\mathrm{S}_{2}$ ).

Is this not, at its most elementary level, what occurred in Shi'ism? When the imam came to inscribe himself in the place of the master, a hierarchical organization was immediately put in place in $S_{2}$ - one that was composed notably of the religious learned and doctors of the Law who presented themselves "as the guardians of doctrinal orthodoxy," bearers, from that point forth, in the structure, of rational and objective knowledge.

Of course, here we are not looking at the wellorganized State that Hegel describes, with its constitution, its higher principles, and the safeguards that institutions represent - this is why the influence of the master tended to wear off in the peripheral zones, thereby permitting the emergence of groups of private interest who put his authority in danger. Nonetheless, what interests us is how the imam (like the Hegelian monarch) preserves the gap between $S_{1}$ and $S_{2}$ in spite of everything: between the performative signifier and the symbolic authority that he represents, and the field of the objective knowledge (of the guardians of the doctrine). What occurred, then, with The Occultation of the twelfth imam, Muhammad al Mahdi (al Kadhim)?

\section{From The Occultation to Khomeinism}

The eleventh imam, al Hasan al Askari, spent his whole life (like his father, the tenth imam) under house arrest in the military camp of Samarra, where he died young. Rumors abounded to the effect that he had left no son, and thus his death divided the faithful into more than a dozen different sects. Tradition has nonetheless given rise to the idea - which has since become of the main articles of faith of Twelver Shi'a Islam that he had left behind a son named Muhammad: it is he who is incarnated in al Mahdi ("The WellGuided One"), the eschatological "Messiah." Muhammad is purported to have been born in the year 256 of the Hijra. With the death of his father, in 260, when he was still very young (four or five years old), he entered what tradition has since termed "the Minor Occultation:" he remained hidden for more than seventy lunar years, only manifesting himself among the faithful through the intermediary of four successive Representatives. But at the end of this first phase of "Occultation," he made it known through a letter addressed to his fourth and last Representative, who was then on his death bed, that he would no longer have any deputies, that any individual claiming to represent him would be an impostor, and that he would only manifest himself to everyone at the End of Time. This announcement marked the start of the "Major Occultation," which still lasts to this day and which shall only come to an end with the advent of Al Qa'im (the imam who arises), when the twelfth imam will return to vanquish the forces of ignorance and injustice. If we come back to our mathemes, at the moment of Major Occultation, the imam $\left(S_{1}\right)$ passes under the bar: from that point forth, he coincides with the inexpressible truth. Through the interplay of permutations between the letters that are specific to the functioning of the mathemes, the $S_{2}$ then takes command of the social bond, triggering a change of discourse one goes from the discourse of the master to the university discourse, in which knowledge $\left(\mathrm{S}_{2}\right)$ is in the place of agent: 


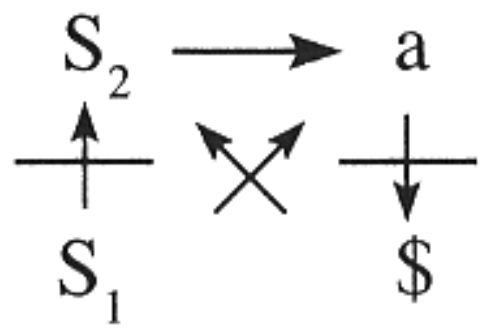

Figure 3: Matheme of the "University Discourse"

The immediate effect of the repression of the master under the bar - that is to say, the closing of the gap between $S_{1}$ and $S_{2}$ that the master supported based on his position of agent in the discourse - touches directly upon the relationship to the Law (which, so Lacan affirmed, always has to do with the Master Signifier, $\mathrm{S}_{1}$ ): as soon as this Law no longer controls knowledge $\left(S_{2}\right)$ from the point of exteriority of the agent of discourse, it will infiltrate it from the inside, to the extent that knowledge will start to proclaim that it coincides with the Law. Let us draw two consequences from this: first of all, one may say here, echoing Kafka, that the (symbolic) Law does not exist - not, as Žižek argues with great pertinence, because the law would be reduced to "an empty imaginary chimera," but on the contrary because it is then transformed "into an impossible Real, a void which none the less functions, exerts influence, causes effects, curves the symbolic space." ${ }^{26}$ Once it has been subsumed under the bar, the Law makes its real effects felt all the more - effects that lie outside the symbolic and which therefore are neither dialectical effects, nor effects that can be interpreted (the Law is then taken à la lettre, at face value). Next, it is knowledge itself that undergoes the effects of this permutation: once the gap between symbolic authority $\left(S_{1}\right.$, in the place of agent) and the register of objective knowledge that is founded on the real entitlements to office of the lawmakers and the theologians $\left(S_{2}\right.$, on the side of the other) is no longer maintained, all in all, once the point of exception that totalizes knowledge from the outside is missing, then "knowledge 'runs amok,'" as Žižek puts it; "the specific neutrality of knowledge takes on an air of malfeasance, its indifference even provokes, in the absence any quilting point, the effect of a superegoic injunction in the subject." 27

It is in this "unquilted" $\mathrm{S}_{2}$ - with neither a master nor an exterior reference point that would be able to totalize it or limit it - that has taken hold of the reins of discourse that one must position the jurist-theologian (Vilayat-e Faqih) of the Khomeini doctrine, through which the dual political and religious mutation of Shi'ism came to be galvanized, a doctrine that had been incubating for long centuries. ${ }^{28}$ Indeed, the historical imams devoted themselves to a mystical brand of initiation that was founded on the esoteric interpretation of the Revelation; on the contrary, the juristtheologian stood for a "rational" knowledge that, according to Khomeinism, is only the objective manifestation of Divine Law. The chief consequence of this was a change in the Guide's political attitude: contrary to the historic imams who promoted quietism, leaving the management of temporal matters to the caliphs, the juristtheologian is spontaneously driven to control policy: he devotes himself to applying his rational theological-juridical knowledge (his "objective" knowledge of sacred things) to the Real itself $\left(\mathrm{S}_{2} \rightarrow a\right)$ in order to have it fall in step with Divine Order.

\section{Bibliography:}

Amir-Moezzi, M.-A. (2007). Le guide divin dans le shî'isme originel. Paris : Verdier.

Amir-Moezzi, M.-A. (2011). Le Coran silencieux et le Coran parlant. Paris : CNRS Editions.

Amir-Moezzi, M.-A. \& Jambet, C. (2004). Qu'est-ce que le shî'isme ?. Paris : Fayard.
Corbin, H. (1999). En islam iranien. Paris: Gallimard. Hegel, G. W. F. (2001). Elements of the Philosophy of Right (1820-1821). (Dyde, S. W. Transl.). Ontario: Batoche Books. Lacan, J. (1991). The Seminar of Jacques Lacan Book I, Freud's Papers on Technique, 1953-1954. (Forrester, J. Transl.). New York / London: Norton \& Co. / Routledge. 
Lacan, J. (1993). The Seminar of Jacques Lacan Book III, The Psychoses, 1955-1956. (Grigg, R. Transl.). New York / London: Norton \& Co. / Routledge.

Lacan, J. (1993). The Seminar Book XI, The Four Fundamental Concepts of Psychoanalysis 1964. (Sheridan, A. Transl.). Harmondsworth: Penguin Books.

Lacan, J. (2007). The Seminar Book XVII, The Other Side of Psychoanalysis 1969-1970. (Grigg, R. Transl.). New York: Norton \& Co.

Žižek, S. (1983). Le stalinisme: un savoir décapitonné. Analytica, 33, Paris: Seuil.

Žižek, S. (2006). The Parallax View. Cambridge, MA / London: The MIT Press.

Žižek, S. (2010). Quatre variations philosophiques sur le thème cartésien. Paris: Germina.

\section{Notes:}

${ }^{1}$ Corbin, H. (1991). En islam iranien. Paris: Gallimard, (4 tomes).

${ }^{2}$ Amir-Moezzi, M. A. \& Jambet, C. (2004). Qu'est-ce que le shî'isme ?, Paris: Fayard, p. 17.

"Here, "discourse" is not to be understood in the customary sense of an "oral development delivered to an audience" [in English: "a speech"], but in the sense of a "modality of social bond:" it refers to the symbolic "structures" of any speech act that, underwriting any speech act, organize the relationships of subjects to one another (by allotting them different places) and allow them to assume the consequences of drive renunciation that is implied by living together side by side.

${ }^{4}$ Amir-Moezzi, M. A. (2011). Le Coran silencieux et le Coran parlant, Paris: CNRS Editions, p. 27-61.

${ }^{5}$ Amir-Moezzi, M.-A. \& Jambet, C. (2004). Qu'est-ce que le shî'isme ?, Op. cit., p. 27-28.

"The noun "Shi'ism" was constructed through antonomasia from the term "Shi'a," which may be translated as "faction" or "party," hence "Shi'a Ali": the "party of Ali."

${ }^{7}$ To be understood in the sense of that which eludes the symbolic, which Lacan was to name "object $a$," the irreducible remainder after any signifying operation.

${ }^{8}$ Linguistics teaches us that signifiers only have any value on account of being differential: each word can be defined only by means of other words. From this indefinite conveyance from one word to another, one may deduce that an isolated signifier $\left(S_{1}\right)$ does not signify anything: it only produces signification when it is articulated with (at least) a second signifier $\left(S_{2}\right): S_{1}-S_{2}$. Hence the principle of solidarity between the primordial pair of signifiers (no $S_{1}$ without $S_{2}: S_{1} \rightarrow S_{2}$ ), which founds both the "discourse of the master" (matrix of the social bond) and (as we are about to demonstrate) the Prophet/imam link (no Prophet without his interpreter).
${ }^{9}$ Here, as is the case across culture in general, besides the discourse of the master, three further discourses coexist (the university discourse, the hysteric discourse, and the analytic discourse), which makes the social bond inhabitable by subjects (when the social realm becomes frozen in one discourse that annihilates all the others, one tips over into totalitarianism). Nonetheless, even when the four discourses coexist, each culture orders the prevalence of one discourse over the others: sociality in Ancient Greece was thus organized as a modality of the discourse of the master, just like the original Shi'ite sociality.

${ }^{10}$ Lacan, J. (1977). The Seminar Book XI, The Four Fundamental Concepts of Psychoanalysis 1964 [1973], edited by J. A. Miller, translated by A. Sheridan. London: Hogarth Press; reprinted by Penguin Books (Harmondsworth, 1993) with an introduction by $D$. Macey, p. 198-199.

${ }^{11}$ Žižek, S. (2010). Quatre variations philosophiques sur le thème cartésien. Paris: Germina, p. 61-62.

${ }^{12}$ Amir-Moezzi, M. A. (2007). Le guide divin dans le shî'isme originel. Paris: Verdier, p. 175.

${ }^{13}$ Amir-Moezzi, M.-A. \& Jambet, C. (2004). Qu'est-ce que le shî'isme ?, Op. cit., p. 134.

${ }^{14}$ Lacan, J. (1993). The Seminar of Jacques Lacan Book III, The Psychoses, 1955-1956, edited by J. A. Miller, translated by R. Grigg, New York / London: Norton \& Co. / Routledge.

${ }^{15}$ Amir-Moezzi, M.-A. \& Jambet, C. (2004). Qu'est-ce que le shî'isme ?, Op. cit., p. 137.

${ }^{16}$ Ibid., p. 61.

${ }^{17}$ Ibid., p. 63.

${ }^{18}$ Ibid., p. 65.

${ }^{19}$ Ibid., p. 69.

${ }^{20} \mathrm{Hegel}, \mathrm{G}$. W. F. (1896). Elements of the Philosophy of Right, [1820 / 1821], translated by S. W. Dyde, London: G. Bell; reprinted by Kitchener, Ontario: Batoche Books, 2001, p. 132-271.

${ }^{21}$ lbid., § 270, p. 205.

${ }^{22}$ Ibid., § 289, p. 235.

${ }^{23}$ Lacan, J. (1991) The Seminar of Jacques Lacan Book I,

Freud's Papers on Technique, 1953-1954, edited by J. A. Miller, translated by J. Forrester, New York / London: Norton \& Co. / Routledge., p. 278.

${ }^{24}$ Žižek, S. (1983). Le stalinisme : un savoir décapitonné. Analytica, Volume 33, Paris: Seuil, p. 65.

${ }^{25} \mathrm{Hegel}, \mathrm{G}$. W. F. (1896). Elements of the Philosophy of Right, Op. cit., § 280 (Addition), p. 230.

${ }^{26}$ Žižek, S. (2006). The Parallax View. Cambridge, MA / London: The MIT Press, p. 39.

27Žižek, S. (1983). "Le stalinisme : un savoir décapitonné", Op. cit., p. 68.

${ }^{28}$ Amir-Moezzi, M.-A. \& Jambet, C. (2004). Qu'est-ce que le shî́isme ?, Op. cit., p. 181-206. 
The author:

Thierry Lamote, PhD

Clinical Psychologist, PhD in Psychopathology and Psychoanalysis, Associate Researcher.

Université Toulouse 2-Le Mirail

5, allées Antonio Machado

31058 Toulouse Cedex 9

France

\section{Electronic reference:}

Thierry Lamote, "A Radical Subversion of the Original Shi'ism - The transformation of the Divine Guide into a 'jurist-theologian'", Research of Psychoanalysis [Online], 18|2014 published Dec. 26, 2014.

This article is a translation of Une subversion radicale du shî'isme originel - La transformation du Guide divin en " juriste-théologien ».

Full text

Copyright

All rights reserved 